\title{
CR-DIOPSIDE AND CR-PYROPE XENOCRYST THERMOBAROMETRY REVISITED: APPLICATIONS TO LITHOSPHERE STUDIES AND DIAMOND EXPLORATION
}

\author{
B.A. KJARSGAARD ${ }^{1}$, K. MATHER ${ }^{2}$, D.G. PEARSON ${ }^{3}$, S. JACKSON ${ }^{1}$, \\ D. CRABTREE ${ }^{4}$ and S. CREIGHTON ${ }^{5}$ \\ ${ }^{1}$ Geological Survey of Canada, Ottawa, Canada; bkjarsga@NRCan.gc.ca \\ ${ }^{2}$ Geological Sciences, Durham University, Durham, United Kingdom \\ ${ }^{3}$ Earth and Atmospheric Sciences, University of Alberta, Edmonton, Canada \\ ${ }^{4}$ Geoscience Laboratories, Ontario Geological Survey, Sudbury Canada
}

We utilize well-characterized suites of mantle peridotite xenoliths and complimentary mantle xenocrysts from the same localities, to revisit the application of pressure temperature (P$\mathrm{T})$ determinations on single grain xenocryst datasets to lithosphere studies and diamond exploration. The applicable thermometers and barometers utilized include the Nimis and Taylor (2000) pyroxene thermobarometer (NT00), and Cr-pyrope garnet thermometers $\left(\mathrm{T}_{\mathrm{Ni}}\right.$ e.g., publications by Griffin et al., 1989; Kjarsgaard, 1992; Canil, 1994; $\mathrm{T}_{\mathrm{Mn}}$ of Creighton, 2009) and barometers $\left(\mathrm{P}_{\mathrm{Cr}}\right.$ of Ryan et al., 1996; $\mathrm{P}_{38}$ of Grütter et al., 2006).

We observe that pyroxene grains from equilibrated lherzolite xenoliths, that have NT00 temperatures above $\sim 1125-1150{ }^{\circ} \mathrm{C}$ may record NT00 P-T conditions that deviate (and in some cases significantly) from the P-T conditions determined by conventional lherzolite thermobarometry i.e., TA98 thermometer of Taylor (1998), and NG85 barometer of Nickel and Green (1985). These deviations can artificially produce 'cooler' and/or 'kinked' paleogeotherms that are not useful representations of lithospheric mantle thickness or heatflow. An important additional issue with application of NT00 thermobarometry are uncertainties related to electron microprobe (EMP) analysis, which is especially relevant to lower $\mathrm{P}-\mathrm{T}$ pyroxene grains, with potentially inherent errors of $\pm 75^{\circ} \mathrm{C}$ and \pm $0.4 \mathrm{GPa}$, that are greater than those of the calibration errors of the thermometer or barometer. To address this issue we provide analytical guidelines for EMP analysis of Cr-diopside to be used for NT00 thermobarometry, based on test using EDS and WDS analyses at varying analytical conditions. The calibration of the $\mathrm{Ni}$ in Cr-pyrope garnet has been contentious; here we present a new, robust calibration based on trace $\mathrm{Ni}$ analysis by LA-ICP-MS and PIXE utilizing our well-characterized mantle peridotite xenolith suites. The pressure conditions determined by $\mathrm{Cr}$ barometry of pyrope garnet provides a minimum base to the depth of the depleted lithosphere, but does not provide a depth to the actual base of the lithosphere. The random sampling of the mantle by kimberlite is an additional complication i.e., the deepest, most depleted peridotites may not be sampled. Furthermore, arrays of P-T points determined by either pyroxene or garnet thermobarometry are used to define paleogeotherms that are qualitatively fitted to Pollack and Chapman (1977; PC77) mantle geotherms (e.g., a 38-mW/m² geotherm). Notably, many xenocryst derived paleogeotherms cut 


\section{0 $^{\text {th }}$ International Kimberlite Conference, Bangalore - 2012}

across multiple PC77 geotherms, which is impossible, unless there have been thermal perturbations in the mantle.

For academic studies of the mantle lithosphere, and applied studies of interest to diamond explorers, the uncertainties and issues noted above make it problematic to utilize single grain thermobarometry to accurately determine mantle heat flow (the paleogeotherm), the base of the lithosphere, and hence the thickness of the 'diamond window'. However, by using the FITPLOT method (McKenzie \& Bickle, 1988; Mather et al., 2011), we are able to input a subset of the xenocryst P-T data, along with crustal heat flow and mantle isentrope data, to quantitatively determine the paleogeotherm and base of the lithosphere. For pyroxene thermobarometry, higher P-T grains are not utilized as input; for garnet thermobarometry, only the highest $\mathrm{P}$ at a given $\mathrm{T}$ are utilized as input.

\section{References}

Canil, D. (1994). An experimental calibration of the nickel in garnet thermometer with applications. Contributions to Mineralogy and Petrology 117, p. $410-420$.

Creighton, S. (2009). A semi-empirical manganese in garnet single crystal thermometer. Lithos, 112, p. 177-182.

Griffin, W.L., Cousens, D.R., Ryan, C.G., Sie, S.H., Suter, G.F. (1989). Ni in chrome pyrope garnets: a new geothermometer. Contributions to Mineralogy and Petrology 103 p. 199-202.

Grütter, H., Latti, D. and Menzies, A. (2006). Crsaturation arrays in concentrate garnet compositions from kimberlite and their use in mantle barometry. Journal of Petrology 47, p. 801820 .
Kjarsgaard, B.A. (1992). Is Ni in chrome pyrope garnet a valid diamond exploration tool? In Current Research, Part E, Geological Survey of Canada, Paper 92-1E, p. 315 - 322.

Mather, K.A., Pearson, D.G., McKenzie, D., Kjarsgaard, B.A. and Priestley, K. (2011). Constraints on the depth and thermal history of cratonic lithosphere from peridotite xenoliths, xenocrysts and seismology. Lithos 125, p. 729-742.

McKenzie, D., Bickle, M.J., 1988. The Volume and Composition of Melt Generated by Extension of the Lithosphere. Journal of Petrology 29, 625-679.

Nickel, K.G., and Green, D.H., 1985. Empirical geothermobarometry for garnet peridotites and implications for the nature of the lithosphere, kimberlites and diamonds. Earth and Planetary Science Letters 73, 158-170.

Nimis, P., Taylor, W.R., 2000. Single Clinopyroxene thermobarometery for garnet peridotites. Part 1, Calibration and testing of a Cr-in-Cpx barometer and an enstatite-in-cpx thermometer. Contributions to Mineralogy and Petrology 139, 541-554.

Pollack, H.N., Chapman, D.S., 1977. Regional variation of heat flow, geotherms, and lithospheric thickness. Tectonophysics 38, 279-296.

Ryan, CG, Griffin, W.L., Pearson, N.J. (1996). Garnet geotherms: A technique for derivation of P-T data from $\mathrm{Cr}$-Pyrope garnets. Journal of Geophysical Research 101, p. 5611-5625

Taylor, W.R., 1998. An experimental test of some geothermometer and geobarometer fomulations for upper mantle peridotites with application to the thermobarometery of fertile lherzolite and garnet websterite. Neues Jarhrbuch fur MineralogieAbhandlungen 172, p. 381-408. 